\title{
Morelet's Crocodile, Crocodylus moreletii (Duméril \& Bibron 1851) (Crocodylidae), Another Nonnative Crocodilian Species Introduced to Florida, USA
}

\author{
Edward F. Metzger III ${ }^{1}$, Michael R. Rochford ${ }^{1}$, Ashley M. Lawrence ${ }^{2}$, and Frank J. Mazzotti ${ }^{1}$ \\ ${ }^{1}$ Fort Lauderdale Research and Education Center, University of Florida, Fort Lauderdale, Florida 33314, USA \\ (efmetzger@gmail.com; mikerochford@hotmail.com; fjma@ufl.edu) \\ ${ }^{2}$ Florida Fish and Wildlife Conservation Commission, Fort Lauderdale, Florida 33314, USA (ashleylawrence1113@gmail.com)
}

$\mathrm{T}$ wo native crocodilian species occur in the state of Florida, USA: the American Alligator (Alligator mississippiensis [Daudin 1802]) and the American Crocodile (Crocodylus acutus [Cuvier 1807]). As a consequence of escapes from zoos and the pet trade, four nonnative species of crocodilians have been introduced to Florida since the 1960s: Spectacled Caiman (Caiman crocodilus [Linnaeus 1758]), West African Slender-snouted Crocodile (Mecistops cataphractus [Cuvier
1825]), Nile Crocodile (Crocodylus niloticus Laurenti 1768), and Schneider's Smooth-fronted Caiman (Paleosuchus trigonatus [Schneider 1801]; Krysko et al. 2016). Of those nonnative crocodilians, $C$. crocodilus is the only species that has established a breeding population (Ellis 1980; Krysko et al. 2016). Herein we report Morelet's Crocodile (Crocodylus moreletii Duméril \& Bibron 1851) as the fifth nonnative species of crocodilian introduced to Florida.

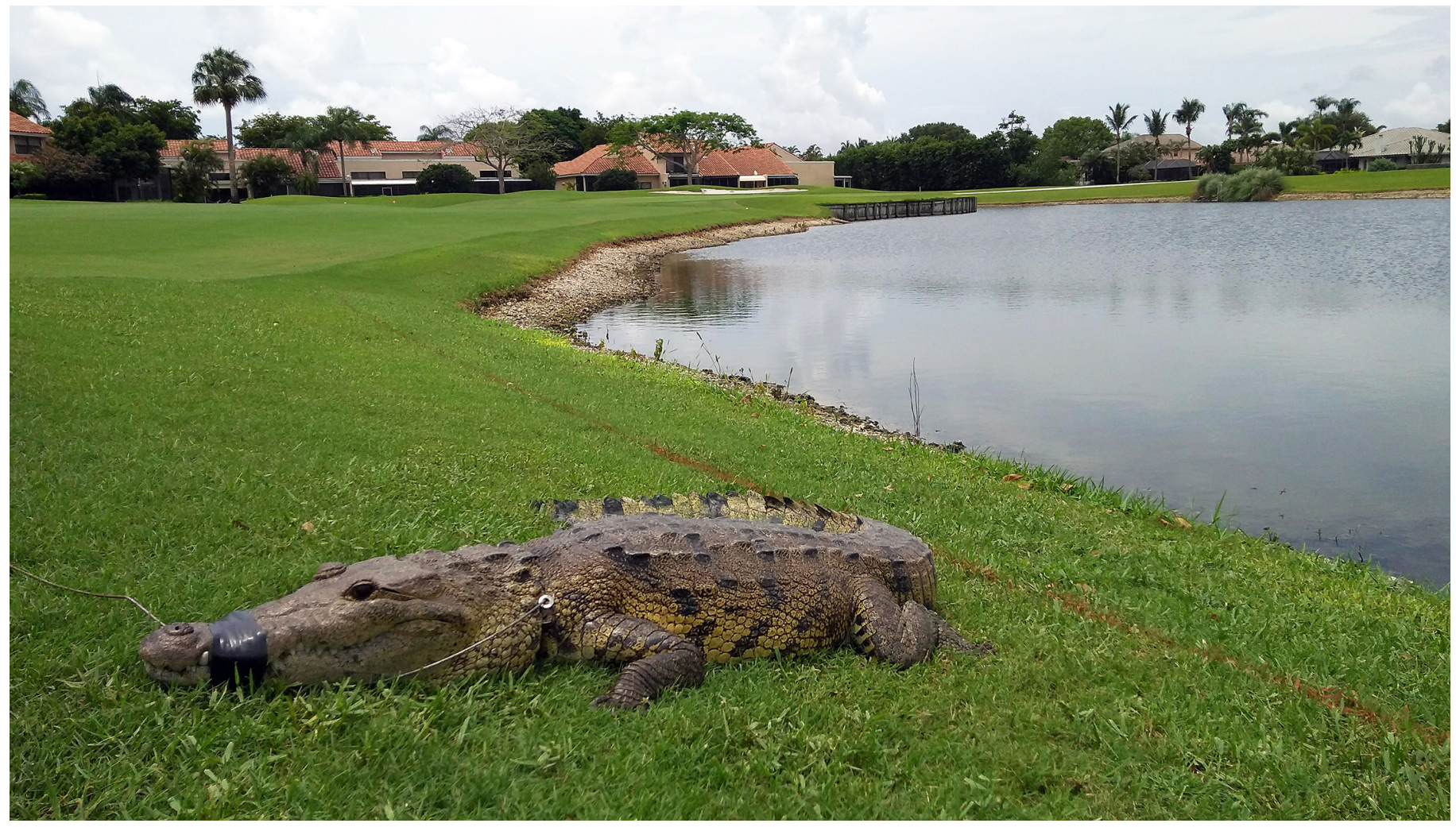

Fig. 1. Morelet's Crocodile (Crocodylus moreletii) (photographic voucher UF-Herpetology 186574) removed from a golf course pond at The Club at Boca Pointe, Palm Beach County, Florida $\left(26.3415263^{\circ} \mathrm{N},-80.1666088^{\circ} \mathrm{W}\right)$ on 31 May 2018. Photograph by Edward F. Metzger III. 
On 31 May 2018, we responded to a report of an unusual crocodile in a golf course pond at The Club at Boca Pointe, Palm Beach County, Florida (26.3415263N, $-80.1666088^{\circ} \mathrm{W}$; datum WGS84). We captured the crocodile using a snatch hook and noose (see Cherkiss et al. 2004) and identified it as an adult female C. moreletii $(\mathrm{SVL}=89.5$ $\mathrm{cm}, \mathrm{TL}=180.4 \mathrm{~cm}$ ) based on the presence of irregular subcaudal scales (Platt and Rainwater 2006; Figs. 1 and 2). It weighed $22.5 \mathrm{~kg}$ and appeared healthy. Leroy Nuñez confirmed the identity of the specimen (photographic voucher UF-Herpetology 186574). Crocodylus moreletii reaches 3-4 $\mathrm{m} \mathrm{TL}$ and is found in fresh and brackish water in Mexico, Belize, and Guatemala.

Approximately two years prior to our capture, the same crocodile was reported to wildlife officials but the responder incorrectly identified the animal as a native $C$. acutus. That this crocodile remained in the wild for two years after being reported suggests that $C$. moreletii has the potential to become established in Florida. However, winters 2016-2017 and 2017-2018 were both warmer than normal (National Weather Service 2017, 2018), which may have facilitated this animal's survival. Crocodylus moreletii could compete with Florida's native crocodilians for food and space, and might

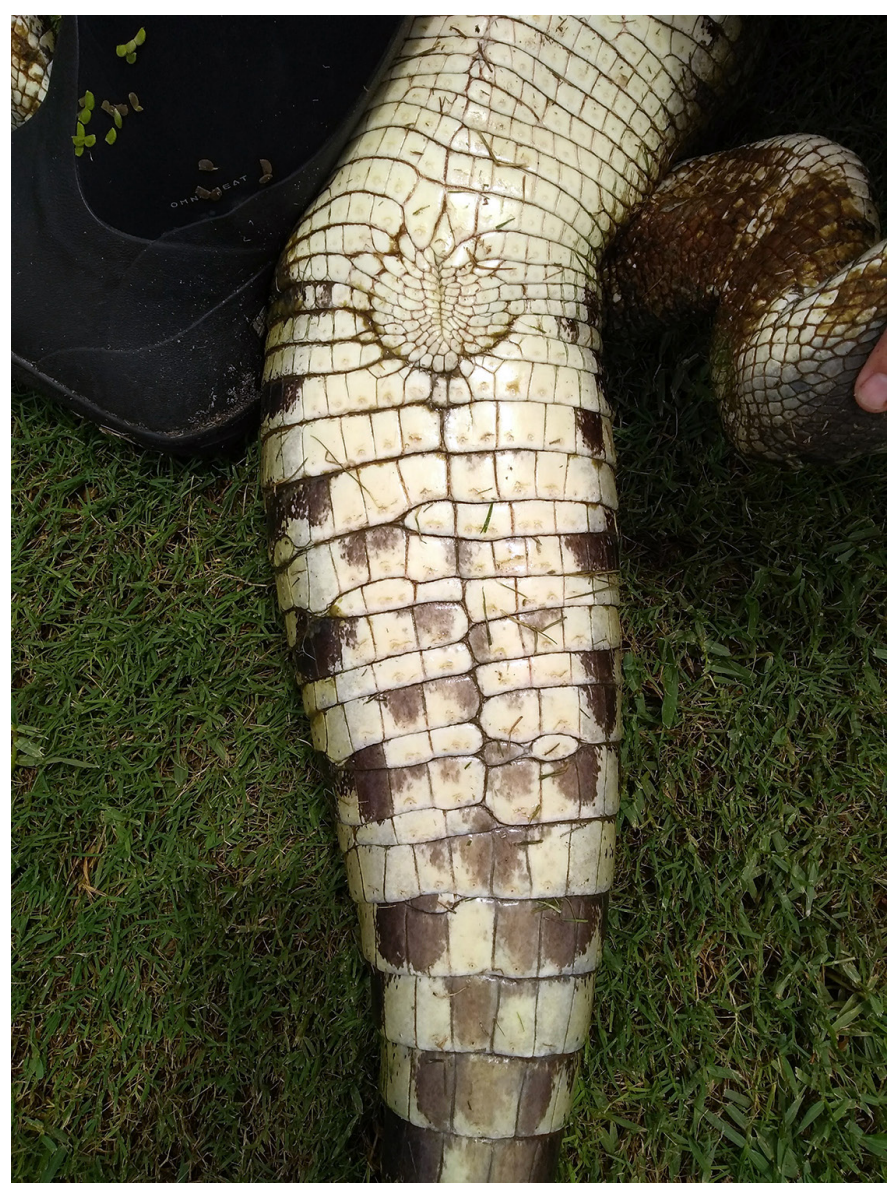

Fig. 2. Irregular subcaudal scales used to confirm identification of a Morelet's Crocodile (Crocodylus moreletii) (photographic voucher UF-Herpetology 186574). Photograph by Edward F. Metzger III. hybridize with federally threatened $C$. acutus (see Ray et al. 2004; Cedeño Vázquez et al. 2008; Rodriguez et al. 2008). Furthermore, if introduced into natural areas in southern Florida, C. moreletii could impede progress toward the Everglades restoration goal of improving native plant and animal species abundance and diversity (USACE SFWMD 1999). Our response and removal highlights the importance of having a dedicated early-detection and rapid-response (EDRR) team trained in identification and safe capture of crocodilians. Behind prevention of new introductions, EDRR is the most feasible and cost-effective means of preventing $C$. moreletii from becoming established in Florida.

\section{Acknowledgements}

We are grateful to Peter Iacono for assistance capturing and collecting data on this crocodile; Eric Suarez for coordinating the response; Sarah Funck and Kristin Laurie for reviewing this manuscript, and The Club at Boca Pointe for granting access. The rapid response was funded through a contract with the South Florida Water Management District. Capture methods were approved by the University of Florida Institutional Animal Care and Use Committee (protocol \#201509072).

\section{Literature Cited}

Cedeño Vázquez, J.R., D. Rodriguez, S. Calmé, J.P. Ross, L.D. Densmore, and J.B. Thorbjarnarson. 2008. Hybridization between Crocodylus acutus and Crocodylus moreletii in the Yucatan Peninsula: I. Evidence from mitochondrial DNA and morphology. Journal of Experimental Zoology Part A: Ecological Genetics and Physiology 309: 661-673.

Cherkiss, M.S., H.E. Fling, F.J. Mazzotti, and K.G. Rice. 2004. Counting and capturing crocodilians. CIR1451. University of Florida Institute of Food and Agricultural Sciences, Gainesville, Florida. <http://edis.ifas.ufl.edu/UW198>.

Ellis, T.M. 1980. Caiman crocodilus: an established exotic in south Florida. Copeia 1980: 152-154

Krysko, K.L., L.A. Somma, D.C. Smith, C.R. Gillette, D. Cueva, J.A. Wasilewski, K.M. Enge, S.A. Johnson, T.S. Campbell, J.R. Edwards, M.R. Rochford, R. Tompkins, J.L. Fobb, S. Mullin, C.J. Lechowicz, D. Hazelton, and A. Warren. 2016. New verified nonindigenous amphibians and reptiles in Florida through 2015, with a summary of over 152 years of introductions. Reptiles \& Amphibians 23: 110-143.

National Weather Service. 2017. South Florida winter 2016-2017 summary. <https://www.weather.gov/media/mfl/news/Feb2017WinterSummary.pdf>.

National Weather Service. 2018. South Florida winter 2017-2018 summary. <https:/www.weather.gov/media/mfl/news/Feb2018WinterSummary.pdf>.

Platt, S.G. and T.R. Rainwater. 2006. A review of morphological characters useful for distinguishing Morelet's Crocodile (Crocodylus moreletii) and American Crocodile (Crocodylus acutus) with an emphasis on populations in the coastal zone of Belize. Bulletin of the Chicago Herpetological Society 41: 25-29.

Ray, D.A., J.A. Dever, S.G. Platt, T.R. Rainwater, A.G. Finger, S.T. McMurry, M.A. Batzer, B. Barr, P.J. Stafford, J. McKnight, and L.D. Densmore. 2004. Low levels of nucleotide diversity in Crocodylus moreletii and evidence of hybridization with C. acutus. Conservation Genetics 5: 449-462.

Rodriguez, D., J.R. Cedeño Vázquez, M.R.J. Forstner, and L.D. Densmore III. 2008. Hybridization between Crocodylus acutus and Crocodylus moreletii in the Yucatan Peninsula: II. Evidence from microsatellites. Journal of Experimental Zoology Part A: Ecological Genetics and Physiology 309: 674-686.

USACE SFWMD. 1999. Central and Southern Florida project comprehensive review study: Final integrated feasibility report and programmatic environmental impact statement. US Army Corps of Engineers, Jacksonville District, South Atlantic Division, Jacksonville, Florida, and South Florida Water Management District, West Palm Beach, Florida. 